\title{
Characteristics And Risk Factors Of Newborn Infants Who Visited Emergency Department
}

Se Hyun Oh, MD., and Sung Shin Kim, MD.

Department of Pediatrics, Soonchunhyang University Bucheon Hospital, Soonchunhyang University College of Medicine, Bucheon, Korea

\section{ABSTRACT}

Purpose: This study aimed to improve emergency care for future neonatal patients.

Methods: We conducted a clinical analysis of neonatal patients who visited the emergency department of Soonchunhyang University Bucheon Hospital from January 2004 to December 2012. We reviewed the medical records of 972 neonates less than 28 days of age.

Results: The male:female ratio was 1.2:1. In terms of patient inflow, the peak month was September (10.3\%), the peak day of the week was Saturday (205\%), and the peak time of the day was 18:00-23:59 (39.0\%). The most common symptom was fever (17.7\%), and final outcomes were as follows: approved discharge (50.1\%), admittance to the hospital (37.6\%), transfer to another hospital (3.2\%), discharge against medical advice $(3.0 \%)$ and death $(0.1 \%)$. There was no difference in the number of visits for irritability based on sex, age of the child, maternal age, parity, gestation, birth weight, type of birth, or season. However, the proportion of discharges was significantly higher in the group comprising the irritable infants (77.4\%) than in the group comprising non-irritable infants $(50.4 \%)(P<0.001)$.

Conclusion: A newborn's transition from intrauterine to extrauterine life involve numerous physiologic and biochemical changes. Some visits are due to non-serious diseases, and reflect insufficient knowledge and information of the parents; this highlights the pressing need for parents' education.

Key Words: Infant, Newborn, Emergency service, Hospital

\section{서론}

신생아기란 출생 후 첫 4주간을 말하며 출생 후 자궁 외 환경에서 생존하기 위한 여러 생리 적 적응 현상이 완성되는 기간으로 매우 불안정하고 취약한 시기이담. 부모 역시 대부분 미 리 준비되어 있지 않은 상태에서 처음 육아를 시작하면서 아직 미숙한 시기로 처음 접하는 상 황들이 낮설고 당황스러울 수 있다. 갑작스러운 아기상태의 변화나 응급상황에서 24 시간 언제 든지 방문 할 수 있는 곳이 병원의 응급실이며 우리나라의 소아환자의 응급실 이용현황에 대 한 보고는 다수 있었으나, 신생아의 응급실 이용에 대한 보고는 부족한 실정이다. 그리고 신생
Received: 12 July 2015

Revised: 1 September 2015

Accepted: 6 September 2015

Correspondence to:

Sung Shin Kim, M.D.

Department of Pediatrics, Soonchunhyang University Bucheon Hospital, Soonchunhyang University College of Medicine, 170 Jomaru-ro, Wonmi-gu, Bucheon 14584, Korea

Tel: +82-32-621-5410

Fax: +82-32-621-5016

Email: kimss@schmc.ac.kr

Copyright(c)

By Korean Society of Neonatology. All right reserved.

This is an Open-Access article distributed under the terms of the Creative Commons Attribution Non-Commercial License (http://creativecommons.org/licenses/ by-nc/3.0), which permits unrestricted non-commercial use, distribution, and reproduction in any medium, provided the original work is properly cited. 
아 시기에 응급실에 내원하게 된 주증상 중 보챔은 신생아 시기에 주로 국한 되는 것으로 대부분 보호자의 주관적인 판단에 좌우되 지만 발열은 체온을 측정함으로써 객관적인 평가가 가능하고, 황 달은 피부의 색으로 확인할 수 있으며 기침구 토, 설사 등은 횟수 등으로 수치화 할 수 있다. 이에 저자는 신생아기의 응급실 이용양 상에 대한 기초자료를 제공하고자 응급실에 내원한 신생아들의 특성과 주관적 판단인 경우가 많은 보챔으로 내원한 신생아에 영 향을 주는 인자들을 분석하고자 하였다.

\section{대상 및 방법}

\section{1. 대상}

2004년 1월 1일부터 20012년 12월 31일까지 8년간 순천향대학 교 부천병원 응급실로 방문한 28 일 이하의 환자 972 명을 대상으 로 하였다. 순천향대학교 부천병원은 경기 서부권의 4 개의 상급종 합병원 중 한 곳이며 부천시내 유일한 상급종합병원으로 총 병상 수는 970병상이다. 2009년에 3차 병원으로 승격되었으며 2001년 2월 22일 지역응급의료센터로 지정되었다. 신생아중환자실의 병 상 수는 연구기간 동안 17병상이었으며 2013년도에 22병상으로 증설되었다.

\section{2. 방법}

환자의 내원 당시의 의무기록지를 통하여 출생 후 나이, 성별, 내원 시 계절, 내원 요일, 방문시간, 주증상, 진단코드 및 입원, 귀 가, 사망, 전원, 자의퇴원 등의 최종 진료처리 형태를 후향적으로 조사분석하였다. 또한 자료를 바탕으로 응급실 내원 환자 중 신생 아의 비율 및 성별, 월별, 계절별, 시간대별 분포, 주증상, 질병분 류별 분포, 최종 결과, 응급실 퇴원 이후의 경과, 보챔을 주증상으

Table1. Annual Distribution of ED Patients and Number of Births of Bucheon and Korea

\begin{tabular}{|c|c|c|c|c|c|}
\hline Year & $\begin{array}{c}\text { Pediatric } \\
\text { patients }\end{array}$ & $\begin{array}{c}\text { Neonatal } \\
\text { patients }\end{array}$ & $\begin{array}{c}\text { Soonchunhyang } \\
\text { Bucheon }\end{array}$ & Bucheon $^{2)}$ & Korea $^{2)}$ \\
\hline 2004 & 7,796 & $124(1.6)$ & 629 & 9,086 & 472,761 \\
\hline 2005 & 8,629 & $111(1.3)$ & 526 & 8,129 & 435,031 \\
\hline 2006 & 8,932 & $117(1.3)$ & 462 & 8,409 & 448,153 \\
\hline 2007 & 8,973 & $105(1.2)$ & 501 & 9,224 & 493,189 \\
\hline 2008 & 11,814 & $107(0.9)$ & 422 & 8,609 & 465,892 \\
\hline 2009 & 13,231 & $106(0.8)$ & 373 & 8,272 & 444,849 \\
\hline 2010 & 13,235 & $97(0.7)$ & 451 & 8,529 & 470,171 \\
\hline 2011 & 12,044 & $105(0.9)$ & 462 & 8,268 & 471,265 \\
\hline 2012 & 13,741 & $99(0.7)$ & 434 & 8,341 & 484,550 \\
\hline Total & 98,395 & $972(1.0)$ & 4,260 & 76,867 & $4,185,861$ \\
\hline
\end{tabular}

Abbreviation: ED, emerency department.
로 내원한 신생아 분석, 응급실을 통해 입원한 신생아에 대한 분석 을 실시하였다. 연구 기간 동안 동일 환자가 내원 날짜가 다른 경 우, 응급실에 2 회 이상의 내원은 각각의 예로 간주하였다. 본 연구 의 모든 통계분석은 SPSS version 14.0 (SPSS Inc., Chicago, IL, USA)와 R version 3.1.3 를 사용하였다. 보챔이 주 증상인 신생아 와 응급실을 통해 입원하게 된 신생아에 영향을 주는 인자들을 파 악하기 위하여 단변량 및 다변량 로지스틱 회귀분석을 실시하여 인자들의 승산비(odds ratio, OR)을 도출하였으며 $P<0.05$ 인 경우 통계적으로 유의한 것으로 간주하였다.

\section{결과}

\section{1. 응급실 내원 소아환자 중 생후 28 일 미만 신생아의 비율 및 성별}

8년간 본원 응급실에 내원한 소아청소년 환자수는 98,395 명이

Table 2. Demographic Characteristics of All Patients

\begin{tabular}{|c|c|}
\hline Variable & Total $(n=972)$ \\
\hline \multicolumn{2}{|l|}{ Sex } \\
\hline Male & $531(54.6)$ \\
\hline Female & $441(45.4)$ \\
\hline Day after birth (d) & $15.4 \pm 8.3$ \\
\hline Marternal age (y) & $31.3 \pm 4.0$ \\
\hline \multicolumn{2}{|l|}{ Parity } \\
\hline Primiparity & $296(56.7)$ \\
\hline Multiparity & $226(43.3)$ \\
\hline \multicolumn{2}{|l|}{ Gestation } \\
\hline Term & $595(91.1)$ \\
\hline Preterm & $53(8.1)$ \\
\hline Postterm & $5(0.8)$ \\
\hline Birth weight (g) & $3,219 \pm 467$ \\
\hline \multicolumn{2}{|l|}{ Type of birth } \\
\hline C-sec & $202(30.3)$ \\
\hline NSVD & $464(69.7)$ \\
\hline \multicolumn{2}{|l|}{ Season of visit } \\
\hline Spring & $241(24.8)$ \\
\hline Summer & $219(22.5)$ \\
\hline Autumn & $272(28.0)$ \\
\hline Winter & $240(24.7)$ \\
\hline \multicolumn{2}{|l|}{ Birth in hospital } \\
\hline Inborn & $68(7.0)$ \\
\hline Outborn & $904(93.0)$ \\
\hline
\end{tabular}

Data was presented as mean \pm SD for continuous variables and count (\%) for categorical variables.

Abbreviation: NSVD, normal spontaneous vaginal delivery. 
었으며(Table 1) 그 중 생후 28일 이하의 신생아는 972명(0.99\%) 이었다. 응급실 내원 신생아의 평균 출생 후 나이는 15.4 일, 평균 출 생 체중은 3,219 g 이었으며, 그 중 남아 531명(54.6\%) 여아 441명 (45.4\%)으로 남녀 비는 1.2:1 로 남아의 수가 더 많았다(Table 2).

\section{2. 월별, 계절별 분포}

월별로 일년 중 9월이 100명(10.3\%)으로 가장 많았으며 10월 98명(10.1\%) 3월 93명(9.6\%) 순이었으며 5월이 62명(6.4\%)으로 가장 적었다(Figure 1). 계절별로는 9월에서 11월까지인 가을이 272 명(28.0\%)으로 가장 많았으며 6월에서 8월까지인 여름이 219 명(22.5\%)으로 가장 적었다(Table 2).

\section{3. 요일별 분포}

요일별로는 토요일이 199명(20.5\%)로 가장 많았으며 일요일 194명(20.0\%), 월요일 132명(13.6\%) 순이었으며 목요일이 100명

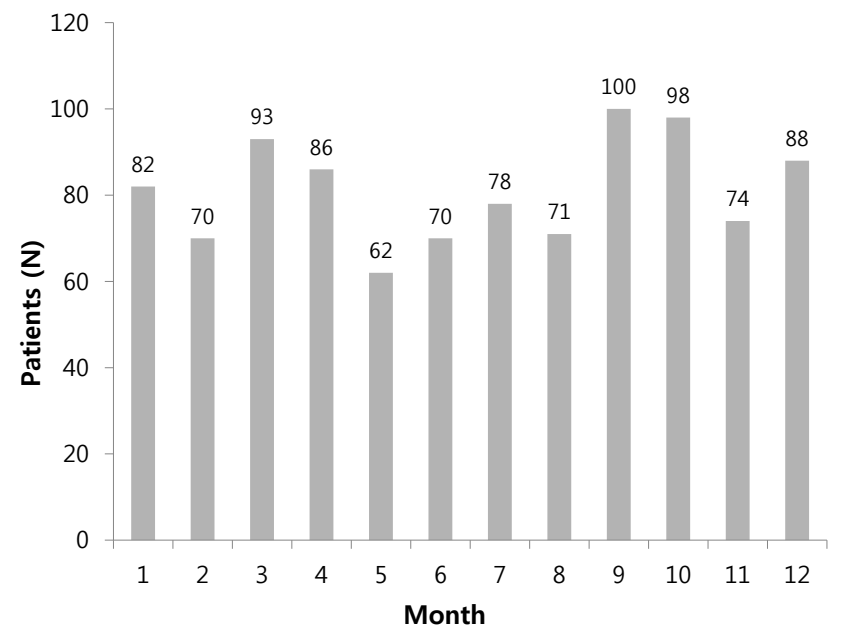

Figure 1. Distribution of visiting month of patients.

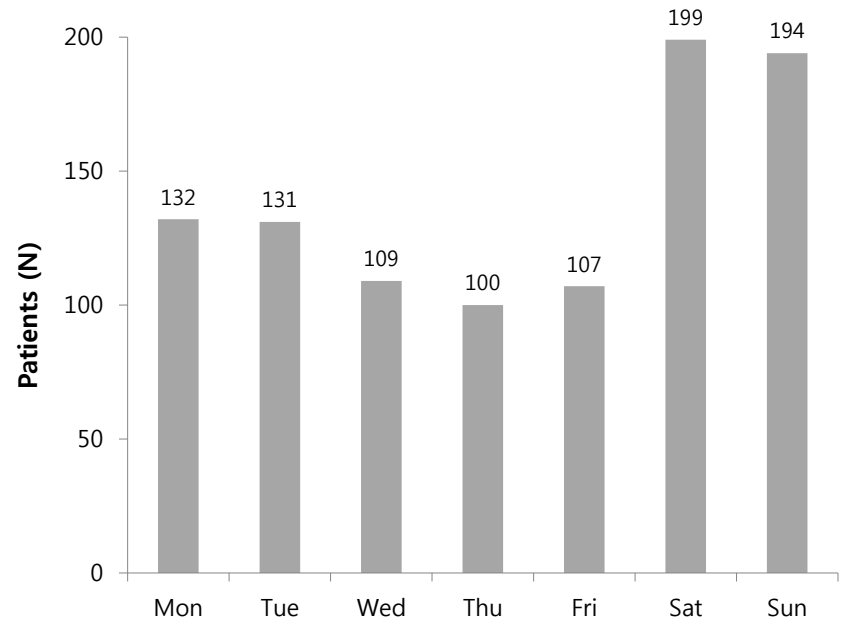

Figure 2. Distribution of visiting day of week of patients.
(10.3\%)으로 가장 적었다(Figure 2).

\section{4. 시간대별 분포}

응급실 방문 시간을 0:00-5:59, 6:00-11:59, 12:00-17:59, 18:0023:59로 구분하였으며 기록 누락으로 인하여 방문시간을 확인하 지 못한 43명의 환자를 제외하고 18:00-23:59에 방문 환자가 378 명(39.0\%)으로 가장 많았으며 06:00-11:59에 137명(14.1\%)로 가 장 적었다(Table 3).

\section{5. 주증상의 분포}

응급실에 내원 시 주증상은 발열이 172명(17.7\%)으로 가장 많 았으며 황달 152명(15.6\%), 보챔 133명(13.7\%), 구토 122명(12.6\%), 기침 96명(9.9\%), 설사 53명(5.5\%), 호흡곤란 36명(3.7\%), 신생아가 사와 심정지가 6 명 $(0.5 \%)$ 순으로 나타났으며, 신생아가사로 추정 되는 5 명 중 3 명은 분만직후 본원으로 이송되어 심폐소생술을 시 행하였음에도 출생 당일 본원 신생아실에서 사망하였고, 1 명은 심 폐소생술 후 타병원으로 전원되었으며, 1명은 본원 신생아중환자 실에서 입원치료 후 퇴원하였다. 응급실에서 사망한 1명은 생후 28 일 된 신생아로 침대 아래쪽에서 자고 있던 중 침대 위에서 떨어진 성인에 의한 외상으로 도착 시 심한 두부외상이 있었으며 사망한 상태였다(Table 4).

발열의 계절별 분포를 보면 봄 44명(25.6\%), 여름 60명(34.9\%),

Table 3. Distribution of the Time of Visit to the ED

\begin{tabular}{lccccc}
\hline Time & $0: 00-5: 59$ & $6: 00-11: 59$ & $12: 00-17: 59$ & $18: 00-23: 59$ & Missing \\
\hline Number & 178 & 137 & 236 & 378 & 43 \\
$\%$ & 18.4 & 14.1 & 24.3 & 39.0 & 4.4 \\
\hline
\end{tabular}

Abbreviation: ED, emerency department.

Table 4. Chief Complaints of the Visiting the ED

\begin{tabular}{lrr}
\hline Diagnosis & $\mathrm{n}$ & $\%$ \\
\hline Fever & 172 & 17.7 \\
Jaundice & 152 & 15.6 \\
Irritability & 133 & 13.7 \\
Vomiting & 122 & 12.6 \\
Cough & 96 & 9.9 \\
Diarrhea & 53 & 5.5 \\
Dyspnoea & 36 & 3.7 \\
Nasal congestion & 23 & 2.4 \\
Feeding problem & 10 & 1.0 \\
Umbilical cord infection & 10 & 1.0 \\
Convulsion & 9 & 0.9 \\
Lethargy & 3 & 0.3 \\
Etc & 153 & 15.8
\end{tabular}

Abbreviation: ED, emerency department. 
가을 38명(22.1\%),겨울 30명(17.4\%)으로 여름에 그 빈도가 높았 으며, 기침은 봄 15 명(15.6\%) 여름 17명(17.7\%) 가을 34명(35.4\%), 겨울 30명(31.3\%)으로 가을과 겨울에 그 빈도가 높았다. 주증상 을 월별로 분석하였을 때 1 월에 기침이 14 명(17.1\%), 4월에 구토가 15 명(17.4\%)으로 다른 증상에 비해 가장 많아 전체 통계와 차이를 보였다.

\section{6. 질병분류별 분포}

세계보건기구(World Health Organization, WHO)에서 발표한 국제질병사인분류 10 차 개정판(International Classification of Diseases 10th version, ICD-10)을 바탕으로 code 별 분류를 하 였다. 전산상 코드 입력이 누락되어 분류되지 않은 127명(13.1\%) 을 제외하고, 나머지 대상 군에서 가장 많은 진단코드는 특정 전 염병 및 기생충성 질환 중 A 코드가 245명(25.2\%) 였으며 그 다음 으로 출생전후기에 기원한 특정병태 대한 P 코드가 207명(21.3\%) 이었으며 호흡계통의 질환인 J코드가 150 명(15.4\%) 이었다(Table 5).

\section{7. 응급실 진료 후 최종 결과}

최종 진료 결과를 살펴보면 퇴원이 506명(52.1\%) 입원이 365명 (37.6\%) 이었으며 입원환자 중 199명(54.5\%)이 신생아중환자실에 166 명(45.5\%)이 소아병동으로 입원하였다. 입원을 해야하는 환자 중 본원의 병실 부재나 연고지 등의 문제로 31 명(3.2\%)의 신생아
가 타 병원으로 전원하였으며 29명(3.0\%)은 입원치료를 거부하고 자의퇴원을 하였으며 응급실에서의 사망 1 명 $(0.1 \%)$ 였다. 연구 대 상의 병원은 생후 14 일 이내의 신생아는 신생아중환자실로 입원 하며 그 출생 후 나이가 그 이상일 경우, 중환이 아닌 경우 소아병 동의 1 인실 등으로 입원을 하였고, 14 일 미만 신생아 중 보호자가 환자와 같이 있길 원하는 경우나 Respiratory Syncytial Virus 감 염이 강하게 의심되는 경우 예외적으로 소아병동으로 입원하였다.

\section{8. 응급실 퇴원 이후의 경과}

귀가하였던 신생아 중 외래 진료를 위해 재내원한 환자는 87 명 (16.3\%) 였으며 응급실 퇴원 이후 본원에 방문하지 않은 환자는 448명(83.7\%)으로 귀가 환자의 대부분은 병원에 재내원하지 않 았다.

\section{9. 보챔을 주증상으로 내원한 신생아의 분석}

보챔을 주증상으로 내원한 133 명의 신생아에 관한 인자분석을 하였다. 성별, 출생 후 나이, 산모 나이, 초산부 여부, 재태연령, 출 생체중, 분만방법, 방문계절, 모두에서 통계학적으로 유의한 인자 는 없었다. 산모 나이가 25세 미만인 군의 adjusted OR 1 로 하였 을 때 25-34세 0.4, 35세 이상은 0.44 였으며 엄마가 초산부인 경 우를 1 로 하였을 때 그 외 신생아는 0.4 로 차이는 있으나 통계학적 유의성은 없었다(Table 6).

보챔이 주증상인 군과 그렇지 않은 군을 비교하였을 때 최종 진

Table 5. Distribution of Visits by International Classification of Diseases $10^{\text {th }}$ Version (ICD-10)

\begin{tabular}{|c|c|c|c|}
\hline Code & ICD-10 & n & $\%$ \\
\hline A, B & Certain infectious and parasitic disease & 245 & 25.2 \\
\hline $\mathrm{P}$ & Certain conditions originating in the perinatal period & 207 & 21.3 \\
\hline $\mathrm{R}$ & Symptoms, signs and abnormal clinical and laboratory findings, NEC & 143 & 14.7 \\
\hline K & Diseases of the digestive system & 39 & 4.0 \\
\hline Q & Congenital malformation, deformations and chromosomal abnormalities & 9 & 0.9 \\
\hline $\mathrm{E}$ & Endocrine, nutritional and metabolic disease & 8 & 0.8 \\
\hline $\mathrm{T}$ & Injury, poisoning and certain other consequences of external causes & 6 & 0.6 \\
\hline $\mathrm{H}$ & Disease of eye and adnexa \& ear and mastoid process & 4 & 0.4 \\
\hline M & Diseases of the musculoskeletal system and connective tissue & 1 & 0.1 \\
\hline $\mathrm{N}$ & Diseases of the genitourinary system & 1 & 0.1 \\
\hline S & Injury, poisoning and certain other consequences of external causes & 1 & 0.1 \\
\hline $\mathrm{Y}$ & External causes of morbidity and mortality & 1 & 0.1 \\
\hline None & & 127 & 13.1 \\
\hline
\end{tabular}


Table 6. Results of the Logistic Regression Analysis for the Irritability Group ( $n=133$ )

\begin{tabular}{|c|c|c|c|c|c|c|c|c|}
\hline $\begin{array}{l}\text { Variable } \\
\text { Sex }\end{array}$ & Crude OR & \multicolumn{2}{|c|}{$95 \% \mathrm{CI}$} & $P$-value & Adjusted OR & \multicolumn{2}{|c|}{$95 \% \mathrm{CI}$} & $P$-value \\
\hline Female & 1 & & & & 1 & & & \\
\hline Male & 0.82 & 0.57 & 1.18 & 0.289 & 0.94 & 0.42 & 2.14 & 0.889 \\
\hline \multicolumn{9}{|l|}{ Day after birth } \\
\hline \multicolumn{9}{|c|}{ Maternal age (yr) } \\
\hline$<25$ & 1 & & & & 1 & & & \\
\hline $25-34$ & 0.72 & 0.19 & 4.73 & 0.671 & 0.38 & 0.07 & 2.02 & 0.255 \\
\hline$\geq 35$ & 0.98 & 0.22 & 6.89 & 0.976 & 0.44 & 0.06 & 3.11 & 0.410 \\
\hline \multicolumn{9}{|l|}{ Parity } \\
\hline Primiparity & 1 & & & & 1 & & & \\
\hline Multiparity & 0.5 & 0.26 & 0.91 & 0.029 & 0.42 & 0.18 & 1.01 & 0.053 \\
\hline \multicolumn{9}{|l|}{ Gestation } \\
\hline Term & 1 & & & & 1 & & & \\
\hline Preterm & 1.16 & 0.46 & 2.52 & 0.727 & 1.48 & 0.38 & 5.75 & 0.574 \\
\hline Postterm & - & & - & 0.983 & - & & - & 0.991 \\
\hline \multicolumn{9}{|c|}{ Birth weight (g) } \\
\hline$<2,500$ & 1 & & & & 1 & & & \\
\hline$\geq 2,500$ & 0.7 & 0.32 & 1.77 & 0.410 & 1.34 & 0.28 & 6.51 & 0.716 \\
\hline \multicolumn{9}{|l|}{ Type of birth } \\
\hline C-sec & 1 & & & & 1 & & & \\
\hline NSVD & 0.53 & 0.33 & 0.85 & 0.008 & 0.58 & 0.23 & 1.48 & 0.254 \\
\hline \multicolumn{9}{|l|}{ Season of visit } \\
\hline Spring & 1 & & & & 1 & & & \\
\hline Summer & 0.83 & 0.47 & 1.47 & 0.530 & 0.59 & 0.15 & 2.35 & 0.455 \\
\hline Autumn & 1.31 & 0.8 & 2.16 & 0.290 & 1.52 & 0.49 & 4.73 & 0.470 \\
\hline Winter & 1.12 & 0.66 & 1.89 & 0.676 & 1.85 & 0.6 & 5.72 & 0.288 \\
\hline
\end{tabular}

Abbreviations: OR, odds ratio; CI, confidence interval; NSVD, normal spontaneous vaginal delivery.

Table 7. Outcomes in the Irritability Group

\begin{tabular}{|c|c|c|c|c|c|}
\hline \multirow{2}{*}{ Variables } & \multicolumn{2}{|c|}{ Irritability group } & \multicolumn{2}{|c|}{ Non-irritability group } & \multirow{2}{*}{$\begin{array}{c}\text { Comparison } \\
(P \text {-value })\end{array}$} \\
\hline & $\mathbf{n}$ & $\%$ & $\mathbf{n}$ & $\%$ & \\
\hline \multicolumn{6}{|l|}{ Admission } \\
\hline Discharge & 103 & 77.4 & 403 & 50.4 & $<0.001$ \\
\hline Hospitalization & 25 & 18.8 & 340 & 42.6 & \\
\hline Discharge against medical advice & 3 & 2.3 & 26 & 3.3 & \\
\hline Transfer & 2 & 1.5 & 29 & 3.6 & \\
\hline Death & 0 & 0 & 1 & 0.1 & \\
\hline
\end{tabular}

료형태에서 보챔인 주증상인 군에서 퇴원이 $77.4 \%$, 입원이 $18.8 \%$ 그렇지 않은 군의 퇴원이 $50.4 \%$ 입원이 $42.6 \%$ 로 통계적으로 유의 한 차이가 있었다 $(P<0.001$; Table 7$)$.

\section{0. 응급실을 통해 입원한 신생아에 대한 분석}

입원한 신생아에 대한 인자 분석을 하였으며 남녀 비율, 산모 나
이, 초산부 여부, 재태연령, 분만방법에서 통게적으로 유의한 인자 는 없었다. 방문계절에서는 봄에 비해 가을, 겨울이 통계적으로 의 미있게 적었으며 방문 요일은 월요일에 비해 수요일과 일요일이 통계적으로 의미있게 적었다. 출생후 나이가 어릴수록 입원이 많 았으며, 직접 내원에 비해 타병원에서 전원된 경우가 4.0 배로 입원 이 많으며 통계적으로 유의하였다(Table 8). 
Table 8. Results of the Logistic Regression Analysis for the Admission Group

\begin{tabular}{|c|c|c|c|c|c|c|c|c|}
\hline \multirow{2}{*}{$\begin{array}{l}\text { Variable } \\
\text { Sex }\end{array}$} & \multirow[t]{2}{*}{ Crude OR } & \multicolumn{2}{|c|}{$95 \%$ CI } & \multirow[t]{2}{*}{$P$-value } & \multirow[t]{2}{*}{ Adjusted OR } & \multicolumn{2}{|c|}{$95 \% \mathrm{CI}$} & \multirow[t]{2}{*}{$P$-value } \\
\hline & & & & & & & & \\
\hline Female & 1 & & & & 1 & & & \\
\hline Male & 1.18 & 0.91 & 1.54 & 0.214 & 0.88 & 0.48 & 1.62 & 0.683 \\
\hline Day after birth & 0.94 & 0.93 & 0.96 & $<0.001$ & 0.92 & 0.88 & 0.95 & $<0.001$ \\
\hline \multicolumn{9}{|c|}{ Maternal age (yr) } \\
\hline$<25$ & 1 & & & & 1 & & & \\
\hline $25-34$ & 0.72 & 0.19 & 2.16 & 0.576 & 0.72 & 0.16 & 3.3 & 0.671 \\
\hline$\geq 35$ & 0.89 & 0.23 & 2.96 & 0.857 & 1.06 & 0.18 & 6.19 & 0.950 \\
\hline \multicolumn{9}{|l|}{ Parity } \\
\hline Primiparity & 1 & & & & 1 & & & \\
\hline Multiparity & 1.62 & 1.12 & 2.35 & 0.011 & 1.78 & 0.97 & 3.27 & 0.065 \\
\hline \multicolumn{9}{|l|}{ Gestation (wks) } \\
\hline $37-41$ & 1 & & & & 1 & & & \\
\hline$<37$ & 0.86 & 0.49 & 1.51 & 0.590 & 0.75 & 0.25 & 2.22 & 0.598 \\
\hline$>42$ & 3.3 & 0.48 & 6.48 & 0.287 & - & & - & 0.989 \\
\hline \multicolumn{9}{|l|}{ Birth weight (g) } \\
\hline$<2,500$ & 1 & & & & 1 & & & \\
\hline$\geq 2,500$ & 1.97 & 1.06 & 3.76 & 0.034 & 1.11 & 0.33 & 3.77 & 0.869 \\
\hline \multicolumn{9}{|l|}{ Type of birth } \\
\hline C-sec & 1 & & & & 1 & & & \\
\hline NSVD & 1.35 & 0.97 & 1.88 & 0.076 & 0.91 & 0.44 & 1.9 & 0.810 \\
\hline \multicolumn{9}{|l|}{ Type of visit } \\
\hline Direct & 1 & & & & 1 & & & \\
\hline Transfer & 4.59 & 3.29 & 6.46 & $<0.001$ & 3.98 & 1.68 & 9.4 & 0.002 \\
\hline \multicolumn{9}{|l|}{ Season of visit } \\
\hline Spring & 1 & & & & 1 & & & \\
\hline Summer & 0.92 & 0.63 & 1.34 & 0.670 & 0.66 & 0.27 & 1.61 & 0.360 \\
\hline Autumn & 0.75 & 0.52 & 1.08 & 0.120 & 0.38 & 0.17 & 0.89 & 0.026 \\
\hline Winter & 0.57 & 0.39 & 0.84 & 0.004 & 0.37 & 0.15 & 0.91 & 0.030 \\
\hline \multicolumn{9}{|l|}{ Weekday of visit } \\
\hline Monday & 1 & & & & 1 & & & \\
\hline Tuesday & 0.64 & 0.39 & 1.05 & 0.077 & 0.28 & 0.06 & 1.23 & 0.091 \\
\hline Wednesday & 0.57 & 0.33 & 0.98 & 0.042 & 0.17 & 0.04 & 0.77 & 0.022 \\
\hline Thursday & 0.71 & 0.41 & 1.21 & 0.205 & 0.65 & 0.13 & 3.24 & 0.595 \\
\hline Friday & 0.82 & 0.48 & 1.38 & 0.454 & 0.25 & 0.06 & 1.11 & 0.068 \\
\hline Saturday & 0.78 & 0.5 & 1.22 & 0.279 & 0.27 & 0.07 & 1.1 & 0.068 \\
\hline Sunday & 0.55 & 0.35 & 0.87 & 0.011 & 0.2 & 0.05 & 0.84 & 0.028 \\
\hline
\end{tabular}

Abbreviations: OR, odds ratio; CI, confidence interval; NSVD, normal spontaneous vaginal delivery.

\section{고찰}

최근 국내의 출생아수를 보면 2005년도가 역대 최저로 435,031 명이었으며, 이후 2007년까지 약간의 증가를 보였으나 다시 2009 년까지 감소하다 이후 2012년까지는 점차 증가하여 2012년 출생 아수는 485,455명을 기록하였으며, 연구 대상이 된 병원이 위치한
부천시의 출생아수 변동도 이와 비슷하였다 ${ }^{2}$. 국내 출생아수는 전 반적으로 감소하는 모습을 보였으나 순천향대학교 부천병원의 응 급실 내원 소아환자의 수는 2004년부터 2010년까지 꾸준히 증가 하는 양상을 보였다. 응급실 소아 환자수가 꾸준히 증가한 것이 비해 신생아환자 수의 비율은 약간의 변동이 있으나 지속적인 감 소추세를 보였다(Table 1). 
본 연구에서 남녀의 비는 1.2:1로 소아환자 전체를 대상으로 한 그 동안의 다른 보고들에서 1.4-1.6:1 비해 남녀의 차이가 적었다 3-5)

월별 분포에서는 5월이 가장 적었고, 9월이 가장 많았다. 계절별 로는 여름이 가장 적었고 가을이 가장 많았는데 이는 소아환자 전 체를 대상으로 한 문헌과는 차이가 있었으나 ${ }^{3-5)}$, 9월에 가장 많다 는 결과는 신생아를 대상으로 한 문헌에서 비슷한 결과를 나타내 었다 ${ }^{6)}$. 조사기간의 우리나라의 월별 출생아수를 살펴보면 1월이 가장 많았고 10월과 9월이 각각 3번째 4번째로 많음을 확인할 수 있었다. 월별 출생아수와 완전히 일치하지는 않지만 신생아의 응 급실 내원 빈도는 출생아 수에도 영향을 받을 수 있다고 추정해 볼 수 있겠다. 소아 전체를 대상으로 한 문헌과 월별 계절별 분포 에서는 차이를 보였으나 요일별 분포는 토요일과 일요일에 많고 목요일에 가장 적은 것으로 나타났으며 이는 소아 전체를 대상으 로 한 문헌과 비슷한 결과를 보였다 ${ }^{45}$. 응급실 방문 시간 18:0023:59 사이에 방문한 신생아가 39.0\%로 6:00-11:59 사이의 $14.1 \%$ 에 비해 2.75배나 많음을 알 수 있었으며 이 역시 소아전체를 대상 으로 한 다른 연구들과 비슷하였다 ${ }^{3,4}$. 주말 및 18:00-23:59에 응 급실 내원이 많은 것은 이 시간이 외래 진료의 부재로 인하여 일반 적인 진료가 어려워 응급실을 방문하였던 것으로 생각된다. 1993 년도의 신생아 대상의 우리나라 한 연구에서는 낮 12시부터 오후 4시 59분 사이가 $49.5 \%$ 로 가장 많은 환자가 내원하여 본 연구와 차이를 보였닥)

주증상을 보면 발열로 내원한 경우가 $17.7 \%$ 로 가장 많았고 황 달 $15.6 \%$, 보챔 $13.7 \%$ 순이었으며, 이전 우리나라 연국)에서는 패 혈증, 급성위장관염, 황달 순이었다. Calado 등의의 연구에서는 황 달, 보챔, 발진 순이었으며 발열은 $4 \%$ 로 7 번째 였다. Millar 등 ${ }^{8)}$ 의 연구에서는 황달, 호흡곤란, 수유문제, 보챔 순이었다. 그리고 응 급실 내원에 관한 연구는 아니지만 1339를 통한 전원은 응급실을 통해 이루어 진다는 점을 감안할 때, 관련 연구에 의하면 신생아 전원의 주요 의뢰 이유는 호흡기증상, 패혈증 의심, 위장관계 증상, 심혈관 관련, 미숙아, 황달 순이었다 ${ }^{9)}$. 신생아의 응급실 내원시 주 증상은 이전의 연구와 비슷함을 알 수 있었다. 보챔은 신생아 시기 에 주로 국한 되는 것으로 보챔을 주소로 내원한 환자들의 경우 $77.4 \%$ 가 귀가하였으며 보챔을 주소로 내원하여 입원한 신생아의 대부분은 집에서 체온을 확인하지 않은 채 내원하였으나 응급실 에서 발열이 확인되어 입원하였다. 본 연구에서는 보챔을 주소로 내원한 신생아의 로지스틱 회귀분석에서 adjusted OR 상으로는 통계적으로 유의한 차이를 보인 인자는 없었으나, crude OR 에서 초산부가 경산부에 비해 응급실에 더 많이 내원하였으며, 질식분 만의 경우 제왕절개로 출생한 경우보다 응급실에 더 많이 내원하 였는데 질식분만의 경우 산모의 입원기간이 제왕절개에 비하여 짧아 육아에 대한 교육 시간이 상대적으로 짧을 수 있다. 단순 빈
도만 보았을 때 엄마의 나이가 25세 미만인 경우가 그 이상인 경 우보다 응급실에 많이 방문함을 확인할 수 있었다. Kennedy 등 10 의 연구에 의하며 신생아의 응급실 이용 시 응급, 비응급 군 간에 산모가 초산부인 경우, 산모의 나이가 25세 이하인 경우, 산모의 교육정도가 고졸이하인 경우에서 비응급 질환으로 응급실에 더 많이 내원하였으며 이것이 통계적으로 유의한 것으로 확인되었으 며, Millar 등8)의 연구에서는 소견서를 지참하거나 타병원에서의 전원이 아닌 직접 내원한 신생아에 대한 분석에서 산모의 나이가 21세 미만, 초산부, 편부모인 경우 응급실에 더 많이 내원하였으며 이는 통계적으로 유의하였다. 육아 경험이 미숙한 양육자의 경우 불필요하게 응급실 내원하는 경우가 많음을 의미하는 것으로 신 생아의 퇴원 전에 충분한 교육이 필요하며 육아에 대한 궁금증이 나 정보제공이 수시로 이루어 질 수 있는 통로가 마련된다며 불필 요한 응급실 내원을 줄 일 수 있을 것으로 생각된다.

ICD-10에 따른 질병분류에서는 특정 감염성 및 기생충성 질환 $25.2 \%$, 출생전후기에 기원한 특정병태가 $21.3 \%$, 호흡계통의 질환 이 $15.4 \%$ 으로, 특정 감염성 및 기생충성 질환의 빈도가 높은 것은 발열로 내원한 신생아의 진단명을 일단 Rule Out Sepsis (ROS)로 하였기 때문이라고 생각되며, Sepis 의 경우 A코드로 분류되는데 $\mathrm{P}$ 코드인 Neonatal Sepsis 로 하였다면 출생전후기에 기원한 특정 병태의 빈도가 가장 높았을 것이다. ICD-10에 따른 질병분류는 소아전체를 대상으로 한 연구 중 일부는 사고와 중독이 $24.2 \%{ }^{11)}$, $30.4 \%{ }^{5)}$ 로 가장 빈도가 높았고, 일부는 호흡기계 질환이 $35.7 \%{ }^{12)}$, $26.6 \%{ }^{13)}$ 로 가장 빈도가 높아 본 연구의 결과와 차이를 보였다.

내원 시 최종결과가 입원인 경우는 $37.6 \%$, 타병원으로의 전원이 $3.2 \%$, 자의퇴원이 $3.0 \%$, 응급실에서의 사망 $0.1 \%$ 로 입원치료가 필요한 경우는 $43.8 \%$ 로 소아전체를 대상으로 한 연구의 입원율 $15.5 \%, 25.7 \%, 30 \%$ 에 비하여 높았으며 ${ }^{3-5)}$, 신생아 대상 연구7)에서 의 $59 \%$ 와 비교하였을 때 낮은 비율을 보였다. 응급실 내원 소아 중 신생아의 비율은 적지만 어느 연령층보다 높은 입원율을 보이 는 시기로 신생아의 응급실 내원 시 보다 면밀한 진찰로 감별해야 할 질환을 놓치거나 함부로 귀가시키지 않도록 각별히 유의해야 할 것으로 생각된다.

본 연구는 단일 상급종합병원의 지역응급의료센터를 대상으로 이루어졌고, 의무기록지를 통한 후향적분석을 하였기 때문에 누 락된 정보가 있었다는 제한점이 있다. 그러나 소아 전체를 대상으 로 한 연구는 다수인데 비하여 신생아를 대상으로 한 연구는 1993년 이후로 드물어서 최근의 경향이나 추이를 파악하는 데 있 어 본 연구의 의미를 둘 수 있으며, 추후 계획을 통한 신생아의 응 급실 이용에 대한 연구가 전국적 통계를 바탕으로 이루어져야 할 것으로 생각된다. 


\section{REFERENCES}

1) Ahn HS. Textbook of pediatrics. 10th ed. Seoul: Mirae N Co, 2012.

2) Statistics Korea. Live births by sex and birth order for city, county, and district [Internet]. Daejeon: Statistics Korea. 2015 [cited 2015 Oct 1]. Available from: http://kosis.kr/statHtml/ statHtml.do?orgId=101\&tblId=DT_1B81A03\&conn_path= I2\&language $=\mathrm{en}$.

3) Kwak YH, Kim DK, Jang HY. Utilization of emergency department by children in Korea. J Korean Med Sci 2012;27:1222-8.

4) Yoo JW, Lee JH. Clinical analysis of pediatric patients who visited a general hospital emergency center. Korean J Pediatr 2010;53:314-22.

5) Lee HJ, Park SY, Lee YH, Do BS, Lee SB. Clinical analysis of the pediatric patients seen in the emergency medical center. Korean J Pediatr 2005;48:1061-7.

6) Calado CS, Pereira AG, Santos VN, Castro MJ, Maio JF. What brings newborns to the emergency department?: a 1-year study. Pediatr Emerg Care 2009;25:244-8.
7) Lee C. Application and utilization of the visited newborn at emergency department. J Korean Med Assoc 1994;37:699-704.

8) Millar KR, Gloor JE, Wellington N, Joubert GI. Early neonatal presentations to the pediatric emergency department. Pediatr Emerg Care 2000;16:145-50.

9) Jin KM, Chul LM, Ho YJ, Jing KM. Analysis of Maternal and Neonatal Transport by the 1339 Emergency Medical Information Center in Busan Area. J Korean Soc Neonatol 2011;18: 137-42.

10) Kennedy TJ, Purcell LK, LeBlanc JC, Jangaard KA. Emergency department use by infants less than 14 days of age. Pediatr Emerg Care 2004;20:437-42.

11) Chang MS, Yoon MJ, Lee KO, Kim SN. Clinical and Statistical Studies on Pediatric Emergency Room Patients. J Korean Pediatr Soc 1988;31:86-92.

12) Lee JH, Kim JS, Shin DG, Lee HS. Statistical Studies on Pediatric Emergency Room Patients. J Korean Pediatr Soc 1981;24: 304-10.

13) Ahn YH, Ma TY, Lee JS, Sun H. Statistical Studies on Pediatric Emergency Room Patients. J Korean Pediatr Soc 1977;20:7516. 